\title{
Treatment of high-manganese mine water with limestone and sodium carbonate
}

\author{
Adarlene M. Silva, Emanoelle C. Cunha, Flávia D.R. Silva, Versiane A. Leão*

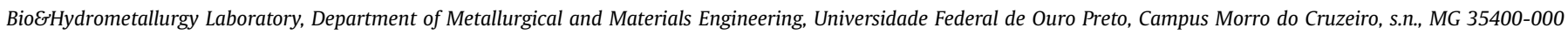
Bauxita, Ouro Preto, Brazil

\section{A R T I C L E I N F O}

\section{Article history:}

Received 16 August 2011

Received in revised form 18 January 2012

Accepted 24 January 2012

Available online 1 February 2012

\section{Keywords:}

Manganese removal

Mine water

Sodium carbonate

Limestone

Manganese carbonate

\begin{abstract}
A B S T R A C T
Manganese is one of the most difficult elements to remove from mine waters, due to its high solubility in both acid and neutral conditions; thus it can be found in quite high concentrations, depending on the rock's mineralogy. Metal carbonate precipitation can be an effective way for its removal, as manganese carbonate has been detected in net alkaline mine waters. However, limestone is effective in removing manganese only if the metal content is low. This research sought to study manganese precipitation from high-manganese $(140 \mathrm{~mL})$ content mine waters applying sodium carbonate and limestone mixtures. It was observed that besides the total carbonate concentration, $\mathrm{pH}$ plays a key role on manganese carbonate formation. Provided the $\mathrm{pH}$ solution is above 8.5, 99.9\% manganese removal can be achieved with carbonate ions. Although not required for manganese precipitation, limestone acts as a solid substrate for the nucleation of fine manganese carbonate grains. Infrared spectroscopy showed manganese carbonate precipitation on the limestone surface. Magnesium was also removed from the mine water but magnesium carbonate formation was not observed.
\end{abstract}

(c) 2012 Elsevier Ltd. All rights reserved.

\section{Introduction}

Mining countries have abundant natural resources, which promotes economic growth and thus wealth (Abraham, 2006). However, mining and metallurgical processes have the potential to produce long term environmental impacts as demonstrated by the Minamata Bay contamination with mercury and the Rio Tinto Estuary contamination with AMD (Franks et al., 2011).

The application of sustainable development concepts in the mining industry has long been welcomed because mining activities, despite affecting relatively small areas, always have environmental impacts including deforestation, vegetation removal, erosion, and landscape alteration (Hilson, 2003). Potential sources of pollution include drainages, air emissions (including particulate matter) and spills (Driussi and Jansz, 2006). Cyanidation tailings, sulfur dioxide and acid mine drainage are among the most cited examples of environmental impacts of the mining sector (Hilson, 2000).

Sustainable development encompasses cleaner production (CP) and pollution prevention (P2) (Basu and van Zyl, 2006). Hilson (2000) argues that CP and P2 are different concepts, particularly in terms of scope. Whereas $\mathrm{CP}$ emphasizes change to a wide range of elements in environmental management, P2 is mainly used to

\footnotetext{
* Corresponding author. Tel.: +55 313559 1102; fax: +55 3135591561.

E-mail addresses: adarlenems@gmail.com (A.M. Silva), versiane@ demet.em.ufop.br, versiane.ufop@gmail.com (V.A. Leão).
}

describe environmental improvements resulting from technological changes. Conversely, Basu and van Zyl (2006) includes CP and P2 in the same umbrella of industrial ecology as a means to achieve sustainable development in a mining context.

Notwithstanding, either CP or P2 will always be a challenge to the mining industry (Hilson, 2003), which has a conservative perspective regarding new technologies. Economic barriers, derived from the commodity aspect of mine products, small R\&D departments, and the lack of top-level management commitment to $\mathrm{CP}$ are the reasons for such challenge (Moors et al., 2005). It has been proposed that the nature of the mining operations along with its unavoidable environmental impacts, make $\mathrm{CP}$ concepts difficult to be applied in the mining context (Hilson, 2003). Nevertheless, CP in mining can be divided into three different categories: (i) managerial changes, (ii) policy changes and (iii) physical changes (Hilson, 2003). The first group comprises performing operations with environmental efficiency, supported by environmental management systems. The second is related to decision-making regarding mining activities, which is carried out through corporate environmental policies and audits. The third includes technological changes and adoption of state-of-art processes and equipment (Hilson, 2003). Examples of such aspects include: sustainable development principles for the disposal of mining wastes (Franks et al., 2011); new water management policies in mining companies (Ringwood and Balfe, 2006); different technologies aiming at waste minimization, treatment and disposal (Franks et al., 2011); 
new pyrometallurgical processes with improved sulfur and carbon sequestration (Moors et al., 2005); and substitution of hazardous chemicals (Grosse et al., 2003), among others.

Many aspects of $\mathrm{CP}$ and $\mathrm{P} 2$ are related to mine waters, including both water management and treatment. This is because the mineral industry utilizes water for a plethora of activities, such as: processing and transport of ores and wastes; mineral beneficiation; dust suppression; washing; extractive metallurgy operations; and human consumption (Kemp et al., 2010). Therefore, water release into the environment is a chief concern both for the industry and environmental agencies (Driussi and Jansz, 2006). Regulations throughout the world define standards for water discharge that must be met by the mining and other industries. These standards can be very strict regarding toxic metals in mine waters.

Manganese is a toxic element usually found in the effluents of many industries, as well as in mine waters, either neutral or acid (AMD). AMD is produced from the oxidation of sulfide minerals as a result of exposure to both oxygen and water during the mining and processing of metal sulfides and coal (Sheoran et al., 2010). Besides manganese, the large content of other elements (mainly iron, aluminum, sulfate and other dissolved materials during acid attack on the mining tailings) found in the AMD is also a concern. Most of these elements can be removed by just increasing drainage $\mathrm{pH}$, which is achieved usually by lime addition. Since metal solubility is reduced as $\mathrm{pH}$ increases, lime is able to reduce metal concentrations and enables drainage compliance with environmental regulations. Metal sulfide precipitation is also applied to remove the transition metal elements, since the residual metal concentrations are very low (Cao et al., 2009; Cohen, 2006). Nevertheless, neither lime nor sulfide ions are effective in removing manganese, as this element is soluble over a wide $\mathrm{pH}$ range and very difficult to remove from contaminated waters; requiring $\mathrm{pH}$ above 11 for an effective removal as hydroxide (Ellis et al., 2000).

$\mathrm{Mn}^{2+}$ oxidation and precipitation as $\mathrm{MnO}_{2}$ followed by clarification is also an alternative to treat manganese-containing drainages. Chemical oxidation can be performed by aeration or applying strong oxidizing agents, such as potassium permanganate, hypochlorite or ozone (Silva et al., 2010). Notwithstanding, the presence of both ferrous iron and organic matter increases oxidant consumption so that iron removal is required prior to manganese oxidation (Ghaly et al., 2007; Gouzinis et al., 1998). Biological processes are an alternative, particularly for low manganese waters (Burger et al., 2008). The metal can also be precipitated as carbonate, since manganese-bearing carbonate minerals such as rhodochrosite $\left(\mathrm{MnCO}_{3}\right)$ and kutnahorite $\left(\mathrm{CaMn}\left(\mathrm{CO}_{3}\right)_{2}\right)$, have been identified in mine-affected waters; thus materials capable of releasing $\mathrm{CO}_{3}^{2-}$ or $\mathrm{HCO}_{3}^{-}$anions have application potential. Kutnahorite precipitation was detected in mine waters with a high content of dissolved calcium, magnesium, manganese and $\mathrm{CO}_{2}$ and its precipitation was enhanced by higher $\mathrm{pH}$ values (Hem and Lind, 1994). It is also proposed that dissolved manganese could precipitate as $\mathrm{MnCO}_{3}$, replacing calcium in calcite or co-precipitating with the latter, provided there is supersaturation with respect to both calcite and rhodochrosite (Lind and Hem, 1993).

Limestone is the most common neutralizing agent for acid waters (Douglas and Degens, 2005) due to its availability (Hammarstrom et al., 2003) and low-cost in many countries and it is likely to be either the first option for metal removal from many wastewaters or be combined with other treatment technologies such as sulfate reduction (Martins et al., 2010). In addition, dissolved carbonate is paramount for manganese carbonate formation; otherwise manganese oxy-hydroxides are produced as already observed in mine waters (Lind and Hem, 1993). Previous work on manganese uptake by limestone showed efficient removal for low to moderate manganese concentrations $(16 \mathrm{mg} / \mathrm{L})$, as well as the presence of manganese carbonate on the limestone surface (Silva et al., 2010). Bamforth et al. (2006) studied manganese $(\sim 3 \mathrm{mg} / \mathrm{L})$ removal from a mine water with a total alkalinity of 3 meq/L by dolomite, limestone, magnesite and quartzite. Besides this, the authors observed kutnahorite formation on quartzite while magnesium-rich calcites were identified in the dolomite and magnesite reactors, suggesting that the magnesium from the substrate minerals may have inhibited manganese carbonate formation. The authors concluded that the nature of the solid substrate does not affect manganese removal.

When alkalinity is not sufficient for manganese precipitation, soluble carbonate sources can be added to the reacting system. Zhang et al. (2010) studied manganese removal with sodium carbonate $\left(\mathrm{Na}_{2} \mathrm{CO}_{3}\right)$ from effluents produced in hydrometallurgical operations. From a $1.76 \mathrm{~g} / \mathrm{L} \mathrm{Mn}$ solution at $\mathrm{pH} 5.9$, manganese precipitation occurred at $\mathrm{pH}$ above 7.5 , reaching $90 \%$ removal at $\mathrm{pH}$ 8.0. Higher removals could have been achieved provided the $\mathrm{pH}$ was further increased. In addition, mineral carbonates such as limestone have been shown to affect the manganese precipitation pathway, hindering manganese carbonate formation. Accordingly, the research described herein was undertaken to assess the effects of both soluble carbonate and limestone on manganese removal from a mine water with high-manganese content.

\section{Experimental}

\subsection{Materials}

A calcite limestone sample assaying $39.5 \%$ calcium and $1.23 \%$ magnesium was kindly provided by Brazilian producers. This sample was first sieved and subsequently dry ground in a vibrating cup mill (Pulverisette 9, Fritsch) and had its particle size distribution assessed by laser diffraction (CILAS -1064 ), which showed $d_{50}$ and $d_{90}$ values of $5.6 \mu \mathrm{m}$ and $18 \mu \mathrm{m}$, respectively. The limestone surface area $\left(1.52 \mathrm{~m}^{2} / \mathrm{g}\right)$ was measured by the $\mathrm{N}_{2}$ adsorption method (Quantachrome Nova 1000).

\subsection{Batch manganese removal experiments}

Manganese removal experiments were carried out with synthetic solutions as well as with mine water. Part of the batch experiments was performed with calcite limestone mixed with sodium carbonate $\left(\mathrm{Na}_{2} \mathrm{CO}_{3}\right)$; the other part being performed with a mixture with either bicarbonate $\left(\mathrm{NaHCO}_{3}\right)$ or sodium hydroxide. Synthetic solutions containing $140-2000 \mathrm{mg} / \mathrm{L}$ manganese $\left(\mathrm{MnCl}_{2} \cdot 4 \mathrm{H}_{2} \mathrm{O}\right)$ prepared at $\mathrm{pH}$ 2.3-6.5 were studied. The experiments were completed with a mine water sample assaying $140.0 \mathrm{mg} / \mathrm{L}$ manganese and at $\mathrm{pH} 6.5$. A volume of $120 \mathrm{~mL}$ solution (synthetic or mine water) was transferred to $250 \mathrm{~mL}$ Erlenmeyer flasks and mixed with different limestone (4.2-20.8 g/L) and sodium carbonate amounts $(0.39-0.92 \mathrm{~g} / \mathrm{L})$. The flasks were kept under agitation $\left(450 \mathrm{~min}^{-1}\right)$, during $90 \mathrm{~min}$, at $23 \pm 2{ }^{\circ} \mathrm{C}$. When the experiments were finished, the $\mathrm{pH}$ value was recorded (Handylab 1 , schott), the solid phase was filtered and the aqueous solution was analyzed for manganese. The effect of time on manganese precipitation was determined in a $2.0 \mathrm{~L}$ open Erlenmeyer flask where $1.5 \mathrm{~L}$ manganese solution was mixed with both limestone $(12.5 \mathrm{~g} / \mathrm{L})$ and calcium carbonate $(0.67 \mathrm{~g} / \mathrm{L})$, at $\mathrm{pH} 6.5$ (initial value). This flask was stirred at $450 \mathrm{~min}^{-1}, 23 \pm 2{ }^{\circ} \mathrm{C}$ and samples were withdrawn at every $5 \mathrm{~min}$ for manganese determination.

\subsection{Continuous manganese removal experiments}

Continuous experiments were carried out in a stirred reactor with a $1.67 \mathrm{~L}$ capacity, at $23 \pm 2{ }^{\circ} \mathrm{C}$. The latter was fed separately 
with (i) a $140 \mathrm{mg} / \mathrm{L}$ manganese-bearing mine water or synthetic manganese solutions and (ii) a blend made up of limestone $(12.5 \mathrm{~g} / \mathrm{L})$ and sodium carbonate $(0.67 \mathrm{~g} / \mathrm{L})$. One experiment was carried out with only sodium carbonate (same concentration); that is, in the absence of limestone. The stirring rate was set at $1200 \mathrm{~min}^{-1}$ and pumping was provided by two peristaltic pumps (Milan 628); one feeding the manganese solution at $24.0 \mathrm{~mL} / \mathrm{min}$ and the second, a limestone-sodium carbonate blend $(4.0 \mathrm{~mL} / \mathrm{min})$. Residence time was set at $60 \mathrm{~min}$ and experiments ran for at least 9 resident times to ensure steady state conditions. After every $60 \mathrm{~min}$, an aliquot was withdrawn from the reactor, filtered and the manganese content and $\mathrm{pH}$ were determined. The solid residue was preserved for further analysis (MEV-EDS and FTIR). Prior to and during the experiments, the mine water was stored in plastic containers at room temperature.

\subsection{Characterization}

Scanning electron microscopy (SEM) was used to examine the morphology of the precipitates. The samples were coated with graphite by electro-deposition, using a JEOL JEE 4C instrument. They were then investigated by a JEOL JSM 5510 scanning electron microscope, with an accelerating voltage $0.5-30 \mathrm{kV}$, equipped with a spectrometer for micro-analysis based on an energy dispersive $\mathrm{X}$ ray spectroscopy system (EDS).

Infrared spectroscopy (FTIR) analyzes were carried out in a Nicolet Nexus 470 model spectrophotometer, equipped with a Centaurus microscope, an attenuated total reflectance (ATR) apparatus (Thermo) and a ZnSe internal reflection devise. Medium infrared measurements were produced with a $\mathrm{KBr}$ bean splitter and an $\mathrm{HgCdTe}$ detector. The samples were pressed against a flat glass surface and mounted under the ATR apparatus. The spectra were collected in the $400-4000 \mathrm{~cm}^{-1}$ region with a minimum of 32 scans at $4 \mathrm{~cm}^{-1}$ resolution.

The mine water was analyzed, before and during the experiments, for metals by using a Varian 725-ES inductively coupled plasma optical emission spectrometer (ICP-OES), or a Perkin Elmer AAnalyst 100 atomic absorption spectrometer and the results are depicted in Table 1 . The major constituents were manganese (140 mg/L), magnesium (90 mg/L) and sulfate (918 mg/L), while the minor elements were iron $(2.2 \mathrm{mg} / \mathrm{L})$, copper $(0.22 \mathrm{mg} / \mathrm{L})$ and zinc $(0.78 \mathrm{mg} / \mathrm{L})$.

\section{Results and discussions}

The CP principles applied to the mine waters included: (i) reducing the production of contaminated mine waters; and (ii)

Table 1

Mine water composition before and after continuous manganese removal experiments. Experimental conditions $12.5 \mathrm{~g} / \mathrm{L} \quad \mathrm{CaCO}_{3}, 0.67 \mathrm{~g} / \mathrm{L} \quad \mathrm{Na}_{2} \mathrm{CO}_{3}, 23 \pm 2{ }^{\circ} \mathrm{C}$. Elemental concentrations are in $\mathrm{mg} / \mathrm{L}$.

\begin{tabular}{lcl}
\hline Parameter & $\begin{array}{l}\text { Initial concentration } \\
\text { (before Mn removal) }\end{array}$ & $\begin{array}{l}\text { Final concentration } \\
\text { (after Mn removal) }\end{array}$ \\
\hline $\mathrm{Ca}$ & 85.6 & 83.10 \\
$\mathrm{Mg}$ & 90.0 & 21.3 \\
$\mathrm{Na}$ & 4.07 & 7.72 \\
$\mathrm{~S}$ & 306.0 & 88.60 \\
$\mathrm{Ni}$ & 0.62 & 0.043 \\
$\mathrm{Zn}$ & 0.78 & 0.075 \\
$\mathrm{Cr}$ & 0.05 & 0.026 \\
$\mathrm{Cu}$ & 0.22 & 0.029 \\
$\mathrm{Fe}$ & 2.20 & 0.73 \\
$\mathrm{Mn}$ & 140.0 & 0.0 \\
$\mathrm{pH}$ & 6.5 & 8.6 \\
\hline
\end{tabular}

recycling and reuse. Specifically, improving effluent quality and optimizing the treatment process so as to comply with the effluent regulations, are two of the most applied approaches (Dharmappa et al., 2000). In this regard, manganese removal is currently one of the greatest challenges.

\subsection{Batch manganese removal}

Manganese can be removed from both mine waters and industrial wastewaters as different compounds and the form of removal is defined by the water's chemistry, specially $\mathrm{pH}$ and Eh values. In oxidizing conditions, manganese oxy-hydroxides are formed, while manganese-bearing carbonate minerals, such as rhodochrosite $\left(\mathrm{MnCO}_{3}\right)$ and kutnahorite $\left(\mathrm{CaMn}\left(\mathrm{CO}_{3}\right)_{2}\right)$, are observed to precipitate naturally in the presence of carbonate ions, if the $\mathrm{pH}$ is in the $7-11$ range (Fig. 1a). Fig. $1 \mathrm{~b}$ presents manganese solubility when considering the precipitation of either manganese carbonate or hydroxide. Manganese carbonate solubility was calculated by Equation (1), presented by Lloyd et al. (1983), where $\mathrm{MnHCO}_{3}^{-}$and $\mathrm{MnOH}^{+}$complexes along with the total carbonate concentrations were considered.

$\left[\mathrm{Mn}^{2+}(\mathrm{aq})\right]=\frac{\left[\mathrm{H}^{+}\right] \cdot K_{\mathrm{sp}}}{\left[\mathrm{CO}_{3}\right]_{\mathrm{tot}} \cdot K_{a, 2}}+\frac{K_{w} \cdot K_{\mathrm{III}}}{\left[\mathrm{H}^{+}\right]}+K_{\mathrm{II}} \cdot\left[\mathrm{H}^{+}\right]$

where $\left[\mathrm{H}^{+}\right]$was the hydrogen ion concentration; $\left[\mathrm{CO}_{3}\right]_{\text {tot, }}$, total dissolved carbonic species; $K_{\mathrm{sp}}$, the solubility product constant, $K_{\mathrm{II}}$ and $K_{\mathrm{III}}$ the equilibrium constants of Equations (2) and (3),

a
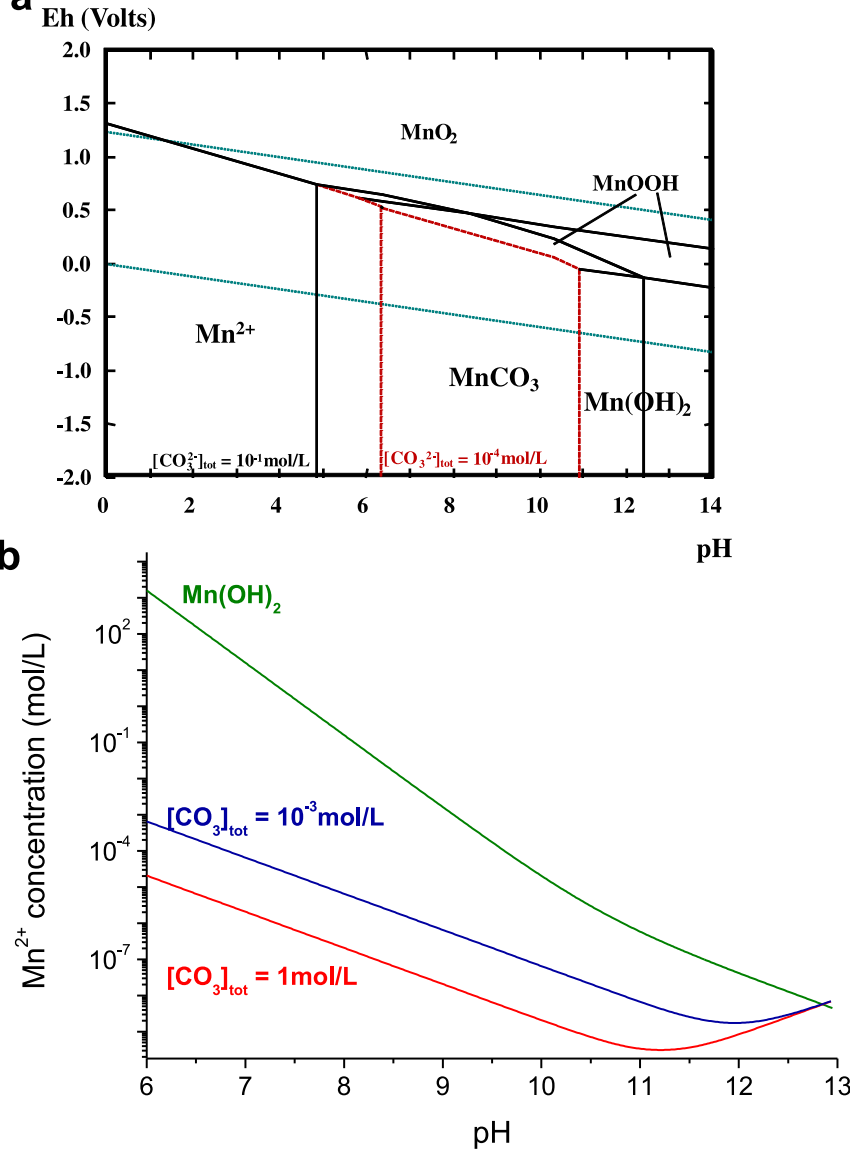

Fig. 1. Eh-pH diagram for manganese carbonate formation (a). Manganese carbonate and hydroxide solubility as a function of $\mathrm{pH}$ at $25^{\circ} \mathrm{C}$ and $\mathrm{I} \mapsto 0$ (b). $\left[\mathrm{CO}_{3}\right]_{\text {tot }}$ represents total dissolved carbonate species. 
respectively; $K_{a, 2}$, was the $\mathrm{H}_{2} \mathrm{CO}_{3}$ second dissociation constant and $K_{w}$, the ionic product of water.

$\mathrm{MnCO}_{3}+\mathrm{H}^{+} \rightleftarrows \mathrm{MnHCO}_{3}^{+}$

$\mathrm{MnCO}_{3}+\mathrm{OH}^{-} \rightleftarrows \mathrm{MnOH}^{+}+\mathrm{CO}_{3}^{2-}$

Equation (1) predicted fairly accurately aqueous manganese concentrations in equilibrium with manganese carbonate (Lloyd et al., 1983). Also included in Fig. 1b is the theoretical manganese hydroxide solubility at $25^{\circ} \mathrm{C}$ and $I \mapsto 0$. In the presence of carbonate ions $\left(10^{-3} \mathrm{~mol} / \mathrm{L}\right.$ dissolved carbonate) and $\mathrm{pH}$ values above 8 , the manganese concentration was reduced to values below $10^{-5} \mathrm{~mol} / \mathrm{L}$. To achieve the same residual concentration, a $\mathrm{pH}$ value of 10 or higher was required when hydroxide precipitation was used. Therefore, carbonate precipitation ensured lower residual manganese concentrations in neutral $\mathrm{pH}$ values when compared to metal hydroxide removal. This observation is consistent with the findings of Dayube and Trindade (2004), who stated that alkalinity was one of the most cost-effective methods for manganese removal from mine waters. Another outcome, demonstrated in Fig. 1 was that carbonate precipitation enabled easier compliance with environmental regulations, as most countries define $\mathrm{pH} 9$ as the maximum allowable value for effluent (or mine water) discharge.

In this work, the approach utilized by Bamforth et al. (2006) was followed; thereby a combination of limestone and soluble carbonate sources was studied. Experiments with synthetic solutions were carried out to determine the amount of both limestone powder $(<45 \mu \mathrm{m})$ and sodium carbonate required for manganese removal from a $140 \mathrm{mg} / \mathrm{L}$ synthetic manganese solution, which was the same as the metal concentration in the studied mine water (Table 1). It can be observed in Fig. 2a, that limestone alone did not remove manganese effectively at such high concentrations. While the $\mathrm{pH}$ increased to 7.9 , the $\mathrm{Mn}^{2+}$ concentration was reduced to $120 \mathrm{mg} / \mathrm{L}$ when $25 \mathrm{~g} / \mathrm{L}$ limestone was applied (Fig. 2a), which was equivalent to a manganese uptake of $0.98 \mathrm{mg} \mathrm{Mn}^{2+} / \mathrm{g}$-limestone. In a previous study by Silva et al. (2010), it was found that this was due to the manganese sorption on calcium carbonate. The authors also observed a $\mathrm{pH}$ increase during manganese removal and similar manganese uptake (1.28 $\mathrm{mg} \mathrm{Mn}^{2+} / \mathrm{g}$-limestone).

Unlike powdered limestone, sodium carbonate precipitated manganese extensively (Fig. 2b), as expected. In the presence of $0.67 \mathrm{~g} / \mathrm{L}$ sodium carbonate, the solution's $\mathrm{pH}$ reached 9.6 and the manganese concentration was reduced to values below the detection limit with the synthetic solution. Lower carbonate concentrations produced lower final $\mathrm{pH}$ values and thus higher residual manganese concentrations in the aqueous phase as demonstrated in Fig. 1b. These results are consistent with the studies carried out by Zhang et al. (2010) during manganese removal from effluents produced in hydrometallurgical operations, which also observed that a $\mathrm{pH}$ value above 8.0 was needed to produce residual manganese concentrations below $1 \mathrm{mg} / \mathrm{L}$. Similarly, Costa (2006) observed smaller residual manganese concentrations for increasing $\mathrm{pH}$ values.

The effect of time on manganese removal is shown in Fig. 3 for experiments comprising the application of different carbonate sources or sodium hydroxide. It can be observed that $12.5 \mathrm{~g} / \mathrm{L}$ limestone reduces the manganese concentration to $124 \mathrm{mg} / \mathrm{L}$, within $100 \mathrm{~min}$; that is, only $11 \%$ of the manganese was removed from the solution. When stoichiometrical concentrations of sodium bicarbonate $(0.21 \mathrm{~g} / \mathrm{L})$ were mixed with a $140 \mathrm{mg} / \mathrm{L}$ manganese solution in the absence of limestone, only a minor effect on metal removal (15\%) was noticed and the final manganese concentration reached $120 \mathrm{mg} / \mathrm{L}$, which was similar to the value observed when only calcium carbonate was applied. When the $\mathrm{NaHCO}_{3}$
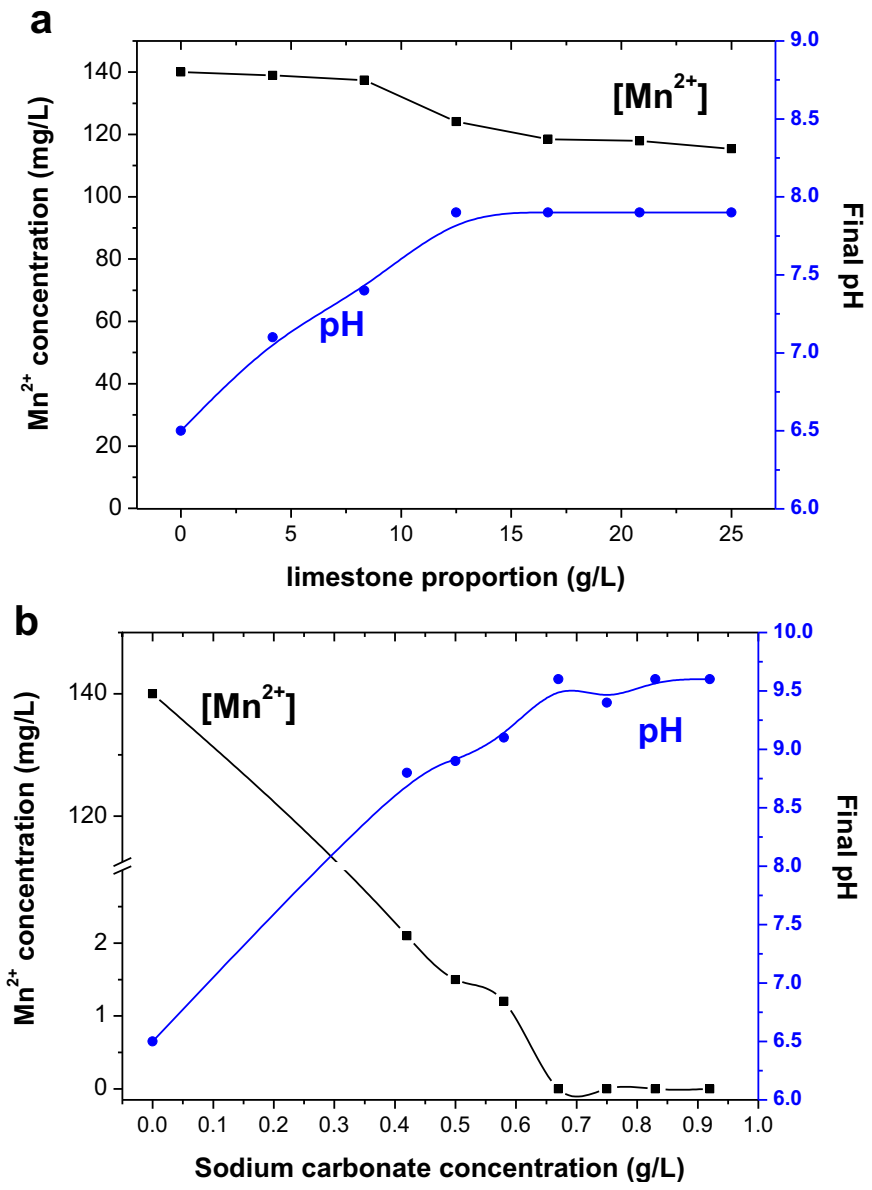

Fig. 2. Effects of powdered limestone proportion (a) and sodium carbonate concentration (b) on manganese removal from synthetic solutions. Experimental conditions: $140.0 \mathrm{mg} / \mathrm{L}$ initial $\mathrm{pH} 6.5,23 \pm 2{ }^{\circ} \mathrm{C}$.

concentration increased to $0.67 \mathrm{mg} / \mathrm{L}$, manganese concentration reduced to $81.8 \mathrm{mg} / \mathrm{L}$ for a final $\mathrm{pH}$ value of 8.0 . This behavior should be compared to the experiments carried out with sodium carbonate (Fig. 4). With $0.26 \mathrm{~g} / \mathrm{L} \mathrm{Na}_{2} \mathrm{CO}_{3}$ (stoichiometrical amount

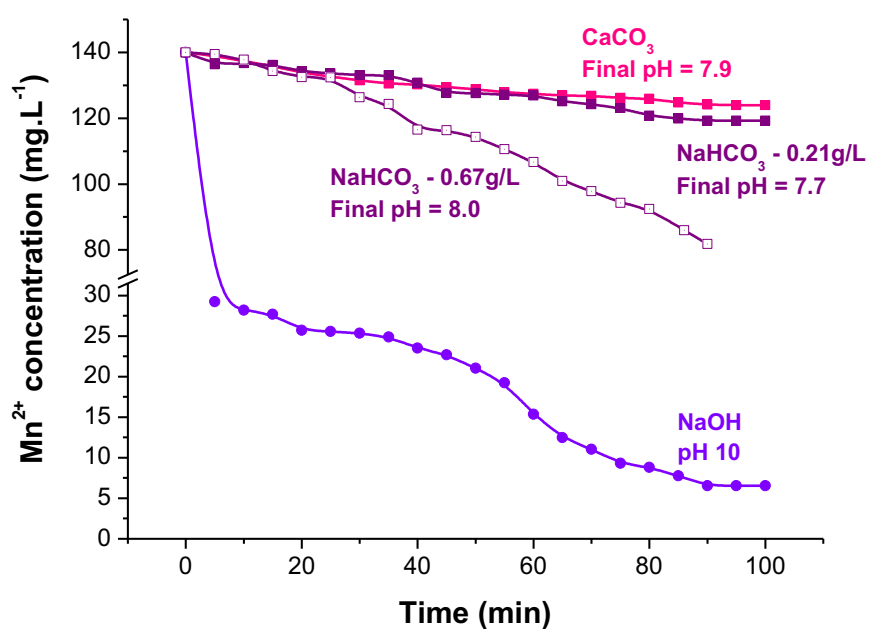

Fig. 3. Effect of different carbonate sources on manganese removal in the absence of limestone powder. Experimental conditions: $140.0 \mathrm{mg} / \mathrm{L} \mathrm{Mn}$ synthetic solutions, limestone $(12.5 \mathrm{~g} / \mathrm{L}$, particle size $<45 \mu \mathrm{m})$ initial $\mathrm{pH} 6.5,0.21 \mathrm{~g} / \mathrm{L}$ or $0.67 \mathrm{~g} / \mathrm{L}$ sodium bicarbonate, $23 \pm 2{ }^{\circ} \mathrm{C}$. 


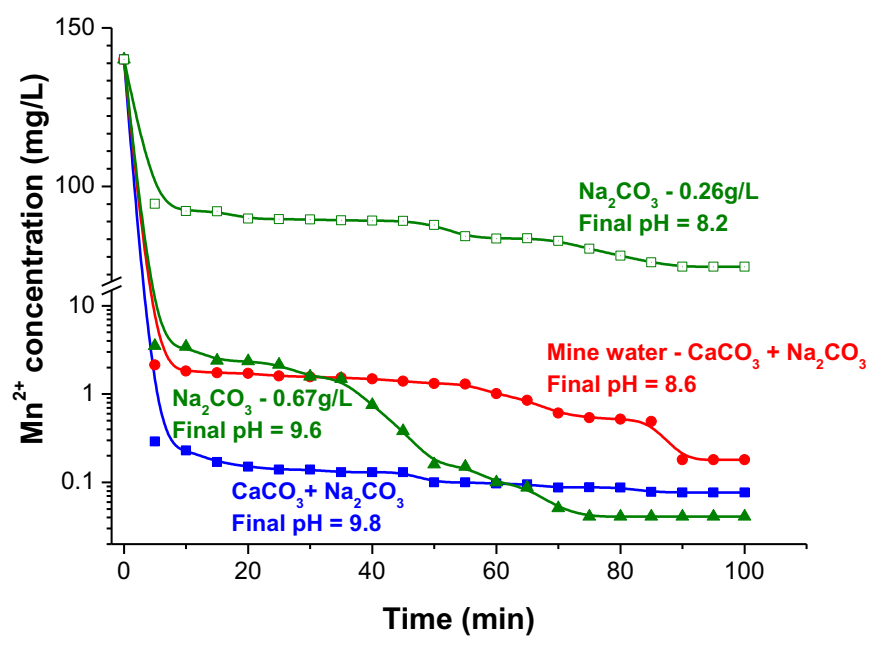

Fig. 4. Influence of time on manganese removal in experiments performed with sodium carbonate. Experimental conditions: $140.0 \mathrm{mg} / \mathrm{L} \mathrm{Mn}$ in both mine water and synthetic solution; $0.26 \mathrm{~g} / \mathrm{L}$ or $0.67 \mathrm{~g} / \mathrm{L}$ sodium carbonate, initial $\mathrm{pH} 6.5,23 \pm 2{ }^{\circ} \mathrm{C}$. Limestone $(12.5 \mathrm{~g} / \mathrm{L}$, particle size $<45 \mu \mathrm{m})$ was added only in the experiments labeled $\mathrm{CaCO}_{3}$. Unless otherwise stated, the experiments were performed with synthetic solutions.

to precipitate $140 \mathrm{mg} / \mathrm{L} \mathrm{Mn}^{2+}$ ) and in the absence of limestone powder, the removal efficiency was improved to $47 \%$ and the manganese concentration was reduced to $74.7 \mathrm{mg} / \mathrm{L}$. For the optimum value defined in Fig. $2 \mathrm{~b}(0.67 \mathrm{~g} / \mathrm{L})$, the residual manganese concentration in solution was below the detection limit; in other words, $100 \%$ removal was achieved. Fig. 3 also shows the effect of $\mathrm{pH}$ on the aqueous manganese concentration. After $100 \mathrm{~min}$, residual metal concentration attained $6.5 \mathrm{mg} / \mathrm{L}$ when the $\mathrm{pH}$ was maintained in 10 with $\mathrm{NaOH}$. With sodium hydroxide, manganese was removed as manganese hydroxide, which was more soluble than the manganese carbonate (species expected in the presence of high carbonate concentrations). From the data presented in Figs. 3 and 4, it is clear that the presence of soluble carbonate species was not the only factor accounting for metal removal, but instead, the $\mathrm{pH}$ had a leading role on the removal efficiency (Sthiannopkao and Sreesai, 2009). Even at higher carbonate concentrations, lower removal efficiencies were observed with sodium bicarbonate (final $\mathrm{pH} 8.0$ ) as compared to sodium carbonate (final $\mathrm{pH} 9.8$ ) or even sodium hydroxide at $\mathrm{pH}$ 10.0. Fig. 1 explains this behavior as it shows lower metal concentrations in equilibrium with manganese carbonate when the $\mathrm{pH}$ increased in the presence of carbonate ions. Fig. 4 also shows a fast reduction in the manganese concentration during the first $5 \mathrm{~min}$, followed by a slower decrease in metal concentration with time and suggests that 90 min was sufficient for the manganese concentration to be stabilized. In addition, manganese removal from the mine water by sodium carbonate-limestone mixtures was slower than that observed from the synthetic solution. The manganese concentration was reduced to $1 \mathrm{mg} / \mathrm{L}$ within $60 \mathrm{~min}$ in the experiments with the latter, while $90 \mathrm{~min}$ was required for the metal concentration to reach $0.18 \mathrm{mg} / \mathrm{L}$, at $\mathrm{pH} 8.6$.

In addition to mine drainages, manganese can be also present in effluents of hydrometallurgical and other industrial operations and concentrations above $1 \mathrm{~g} / \mathrm{L}$ may be found. The element can also be present in leaching liquors, for instance, during sea nodules and nickel laterite leaching (Zhang et al., 2010). In these studies, manganese concentrations were high and the carbonate ions selectively precipitated the manganese in the presence of calcium and magnesium (Zhang and Cheng, 2007b). The carbonate efficiency in increasing $\mathrm{pH}$ along with the manganese removal, was assessed from synthetic solutions, in which the manganese concentration varied from $300.0 \mathrm{mg} / \mathrm{L}$ to $2000.0 \mathrm{mg} / \mathrm{L}$, prepared at an initial $\mathrm{pH}$ value of 2.3. Fig. 5 shows that high-manganese removal could be achieved provided sufficient carbonate was added to the system. A residual manganese concentration below $1 \mathrm{mg} / \mathrm{L}$, along with solution $\mathrm{pH}$ values above 8.8 , was observed for above mentioned tested manganese concentrations. These results are consistent with the work of Jimenez et al. (2004) and Silva et al. (2010).

\subsection{Continuous manganese removal}

Continuous experiments were carried out as the preliminary step of a future pilot scale test. Such experiments were performed with both the synthetic solution and the mine water. Manganese removal was faster when synthetic solutions were studied, as the metal concentration was reduced from $140 \mathrm{mg} / \mathrm{L}$ to $0.8 \mathrm{mg} / \mathrm{L}$ in the presence of both limestone $(12.5 \mathrm{~g} / \mathrm{L})$ and sodium carbonate $(0.67 \mathrm{~g} / \mathrm{L})$ (Fig. 6), while the $\mathrm{pH}$ decreased from 10.2 to 8.5 in the first two resident times. After 8 resident times ( $480 \mathrm{~min}$ ) and under the same conditions, the manganese concentration reached a concentration of $0.81 \mathrm{mg} / \mathrm{L}$ at $\mathrm{pH}$ 8.8. In the experiment carried out only with sodium carbonate, the final concentration was similar $(0.81 \mathrm{mg} / \mathrm{L})$; however, with a slower precipitation rate (likely due to the absence of limestone in the reactor, which would have acted as a surface for heterogeneous nucleation). This finding is supported by Aziz et al. (2008), who stated that the presence of solid limestone improves metal removal efficiencies. When the initial $\mathrm{pH}$ was 2.3, manganese removal was also high because a higher sodium carbonate concentration was applied $(0.83 \mathrm{~g} / \mathrm{L})$ that increased the solution $\mathrm{pH}$ to the $7.1-9.2$ range.

It was also noticed that sulfate removal (Table 1) did not impair manganese precipitation. This phenomenon was observed in a previous work when powdered limestone was applied for manganese removal from a $16 \mathrm{mg} / \mathrm{L} \mathrm{Mn}^{2+}$ and $2400 \mathrm{mg} / \mathrm{L}$ sulfate mine water. Silva et al. (2010) observed a reduction of the manganese removal from mine waters as compared to synthetic solutions and this was ascribed to sulfate precipitation on the limestone surface. As shown in Table 1, the sulfate concentration (determined as total sulfur by ICP-OES) was reduced from $918 \mathrm{mg} / \mathrm{L}$ to $265 \mathrm{mg} / \mathrm{L}$, which is slightly above the $250 \mathrm{mg} / \mathrm{L}$ discharge limit set by many countries worldwide. Other transition metal elements, although in

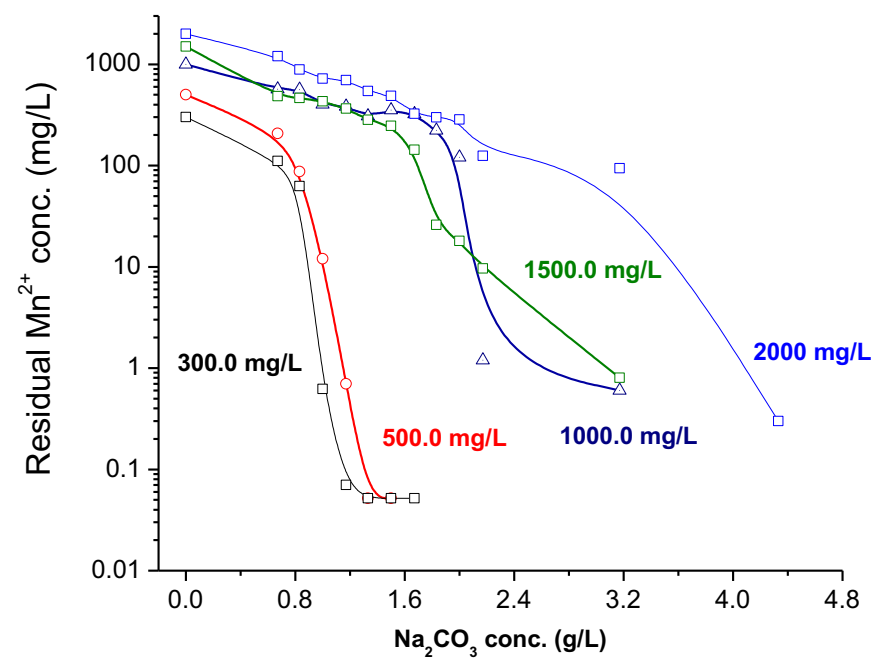

Fig. 5. Effect of sodium carbonate concentration in manganese removal from synthetic solutions. Experimental conditions: 90 min experiments, pH 2.3 (initial); limestone $(12.5 \mathrm{~g} / \mathrm{L}$, particle size $<45 \mu \mathrm{m}), 23 \pm 2{ }^{\circ} \mathrm{C}$ 


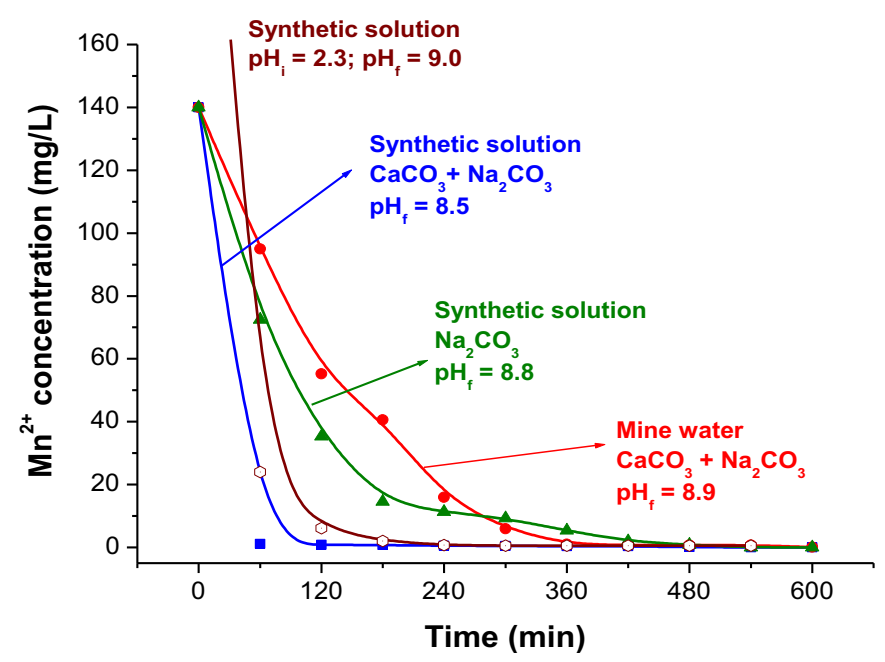

Fig. 6. Manganese removal with limestone-sodium carbonate mixtures in continuous experiments with synthetic solutions and the mine water. Experimental conditions: $0.67 \mathrm{~g} / \mathrm{L}$ sodium carbonate, $\mathrm{pH} 6.5$ (initial value) and $23 \pm 2^{\circ} \mathrm{C}$. Limestone $(12.5 \mathrm{~g} / \mathrm{L}$, particle size $<45 \mu \mathrm{m}$ ) was added only in the experiments labeled $\mathrm{CaCO}_{3}$. One experiment was carried out with synthetic solution ( $300 \mathrm{mg} / \mathrm{L} \mathrm{Mn}^{2+}$ ), at initial $\mathrm{pH} 2.3$ and $0.83 \mathrm{~g} / \mathrm{L}$ sodium carbonate. Residence time: $60 \mathrm{~min}$.

low concentrations, were also removed during treatment. These metals were shown to precipitate as either carbonates $\left(\mathrm{FeCO}_{3}\right.$ and $\mathrm{ZnCO}_{3}$ ) or mixed hydroxide-carbonate compounds (Djedidi et al., 2009), which seemed to be the case for copper and lead in the present work. Nevertheless, sulfate may have affected manganese removal kinetics, since its removal from mine water was slower than from synthetic solutions and this was also observed in batch experiments (Fig. 4). Notwithstanding, sulfate sorption by limestone is currently being investigated.

\subsection{Characterization}

As high carbonate concentration and $\mathrm{pH}$ values were utilized in the present work, manganese removal as carbonate was expected as shown in Fig. 1a; thereby infrared spectroscopy was applied to confirm manganese carbonate formation. This was achieved by analyzing the solid material produced during manganese removal by limestone-sodium carbonate blends. Fig. 7 shows the spectra of limestone before and after contact with the manganese-laden solutions. The spectrum of a sample of pure manganese carbonate is also presented for comparison. For pure calcite limestone, a characteristic band assigned to the $\mathrm{C}=\mathrm{O}$ shift was seen at $712 \mathrm{~cm}^{-1}$. This absorption band was also observed at $724 \mathrm{~cm}^{-1}$ for pure manganese carbonate, as proposed by the NassrallahAboukais et al. (1998), who found this characteristic band at $726 \mathrm{~cm}^{-1}$ for rhodochrosite. Also, Makreski and Jovanovski (2003) observed $\mathrm{C}=\mathrm{O}$ shifts at $712 \mathrm{~cm}^{-1}$ and $722 \mathrm{~cm}^{-1}$, assigned to $\mathrm{CaCO}_{3}$ and $\mathrm{MnCO}_{3}$ in kutnahorite $\left(\mathrm{CaMnMg}\left(\mathrm{CO}_{3}\right)_{2}\right)$. Similarly, this $\mathrm{C}=\mathrm{O}$ band was observed at $728 \mathrm{~cm}^{-1}$ for manganese carbonate by Santillán and Williams (2004). In addition to the $\mathrm{C}=\mathrm{O}$ band at $712 \mathrm{~cm}^{-1}$ (limestone), Fig. 7 also shows a smaller IR shift at $724 \mathrm{~cm}^{-1}$ in the manganese-containing limestone produced in the experiments with the mine water and those carried out with synthetic solutions containing $300 \mathrm{mg} / \mathrm{L}$ (ppt. I) and $1500 \mathrm{mg} / \mathrm{L}$ (ppt. II) manganese (Fig. 5). The formation of manganese carbonate was confirmed by FTIR and the $\mathrm{C}=0$ band at $724 \mathrm{~cm}^{-1}$ was easily seen when the mass of precipitated manganese carbonate was larger (ppt. II). These results are supported by XPS studies on manganese-calcite interactions (Blanchard and Baer, 1992).
Bamforth et al. (2006) studied metal carbonate precipitation in the presence of limestone aiming to treat a mine water containing up to $5 \mathrm{mg} / \mathrm{L}$ manganese in the presence of calcium $(\sim 200 \mathrm{mg} / \mathrm{L})$ and magnesium $(80-100 \mathrm{mg} / \mathrm{L})$. Manganese carbonate was not observed on the surface of limestone even though the mine water presented $2 \mathrm{meq} / \mathrm{L}$ total alkalinity. Contrarily, magnesium calcite was the only described precipitate on the surfaces of dolomite, magnesite or limestone and it was suggested that the presence of magnesium inhibited manganese carbonate formation. For the mine water studied in the present work, Table 1 suggests that the calcium removal was negligible, likely derived from limestone dissolution during the experiments as previously discussed (Fig. 2). Conversely, magnesium was also removed from the mine water, as its concentration was reduced from $90.0 \mathrm{mg} / \mathrm{L}$ to $21.3 \mathrm{mg} / \mathrm{L}$. Nevertheless, $\mathrm{MgCO}_{3}$ which has the $\mathrm{C}=\mathrm{O}$ characteristic band at $749 \mathrm{~cm}^{-1}$ (Grzechnik et al., 1999) could not be detected in Fig. 7, possibly due to the low $\mathrm{MgCO}_{3}$ amount co-precipitated with manganese. The findings of Bamforth et al. (2006) seem to be related to the high $\mathrm{Mg} / \mathrm{Mn}$ ratio ( $>20$ ) in the mine water studied, which did not seem to be the case herein presented where the initial $\mathrm{Mg} / \mathrm{Mn}$ ratio was 0.64 .

The precipitates were also analyzed by SEM-EDS. Fig. 8 depicts limestone particles containing manganese produced under different conditions. Fig. $8 \mathrm{a}$ and $\mathrm{b}$ shows both the images and the EDS spectra of the solid material produced in the experiment with the mine water, while Fig. $8 \mathrm{c}$ and d shows limestone particles containing manganese precipitated in the experiments utilizing $300 \mathrm{mg} / \mathrm{L}$ and $2000 \mathrm{mg} / \mathrm{L}$ of $\mathrm{Mn}^{2+}$, respectively. All the EDS spectra showed calcium which was an indication that the larger particles were limestone, whereas Fig. $8 \mathrm{~b}$ and c depicts manganese mapping. While the EDS spectra identified manganese on the surface of all the analyzed limestone particles, Fig. $8 \mathrm{~b}$ and $8 \mathrm{c}$ suggests that manganese carbonate precipitated as very fine crystals, which was further supported by (i) an increase in both surface and micropore areas from $1.54 \mathrm{~m}^{2} / \mathrm{g}$ and $2.20 \mathrm{~m}^{2} / \mathrm{g}$ to $4.45 \mathrm{~m}^{2} / \mathrm{g}$ and $5.30 \mathrm{~m}^{2} / \mathrm{g}$, respectively; (ii) a reduction on $d_{50}$ of the particle size distribution from $5.6 \mu \mathrm{m}$ to $3.6 \mu \mathrm{m}$, which suggested a higher proportion of fine particles.

The produced manganese carbonate, although contaminated with magnesium, can be blended with manganese carbonate and

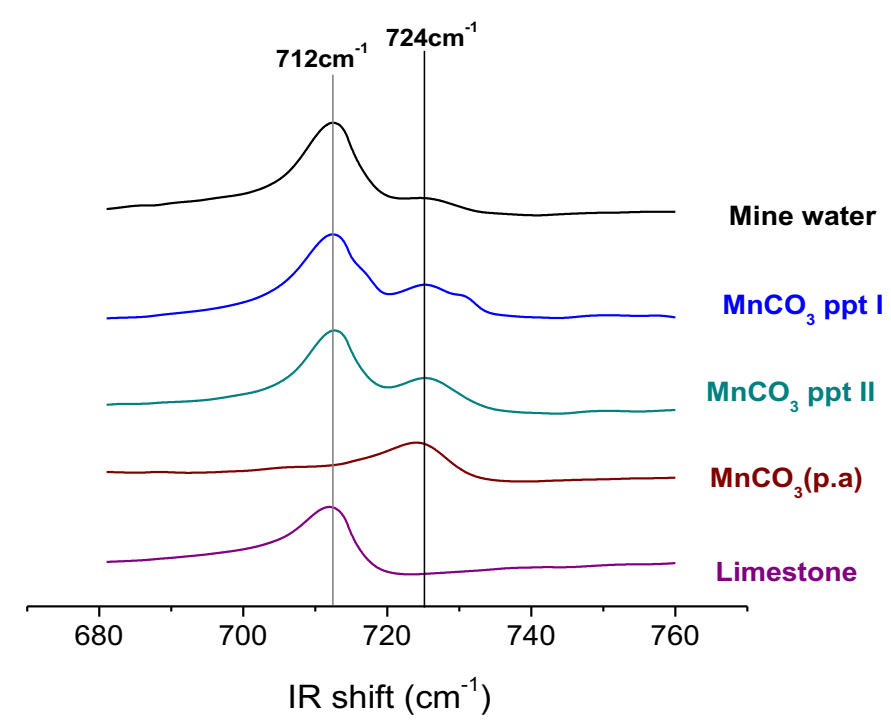

Fig. 7. Infrared spectra of pure manganese carbonate, limestone and manganese carbonate precipitated on limestone surface. The mine water contained $140.0 \mathrm{mg} / \mathrm{L}$ $\mathrm{Mn}(\mathrm{II})$, where ppt. I and ppt. II refer to manganese-laden limestone precipitated from $300 \mathrm{mg} / \mathrm{L}$ (ppt. I) and $2000 \mathrm{mg} / \mathrm{L}$ (ppt. II) respectively. 


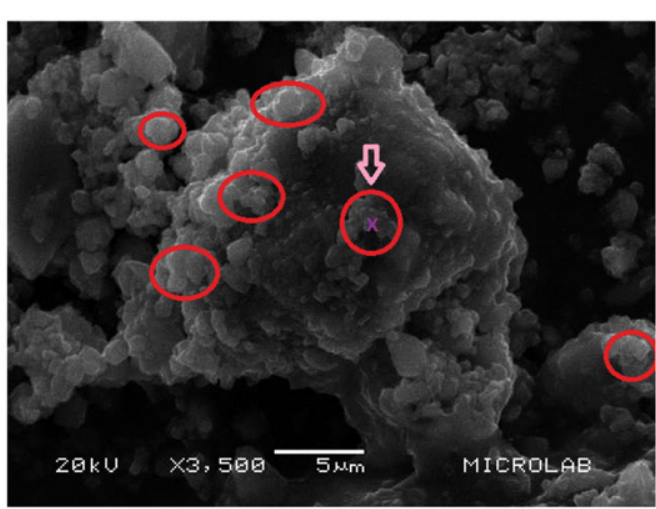

a
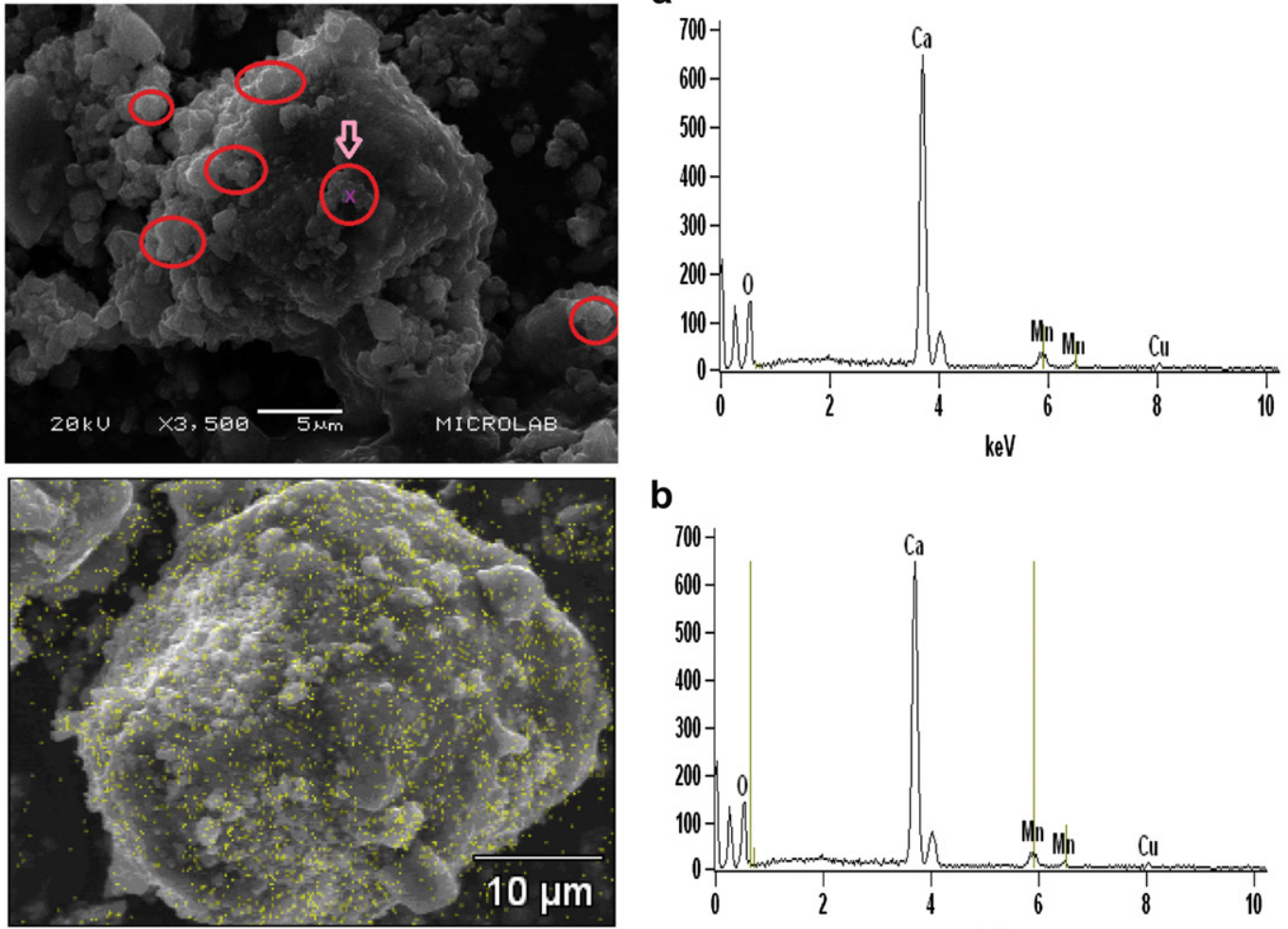

b
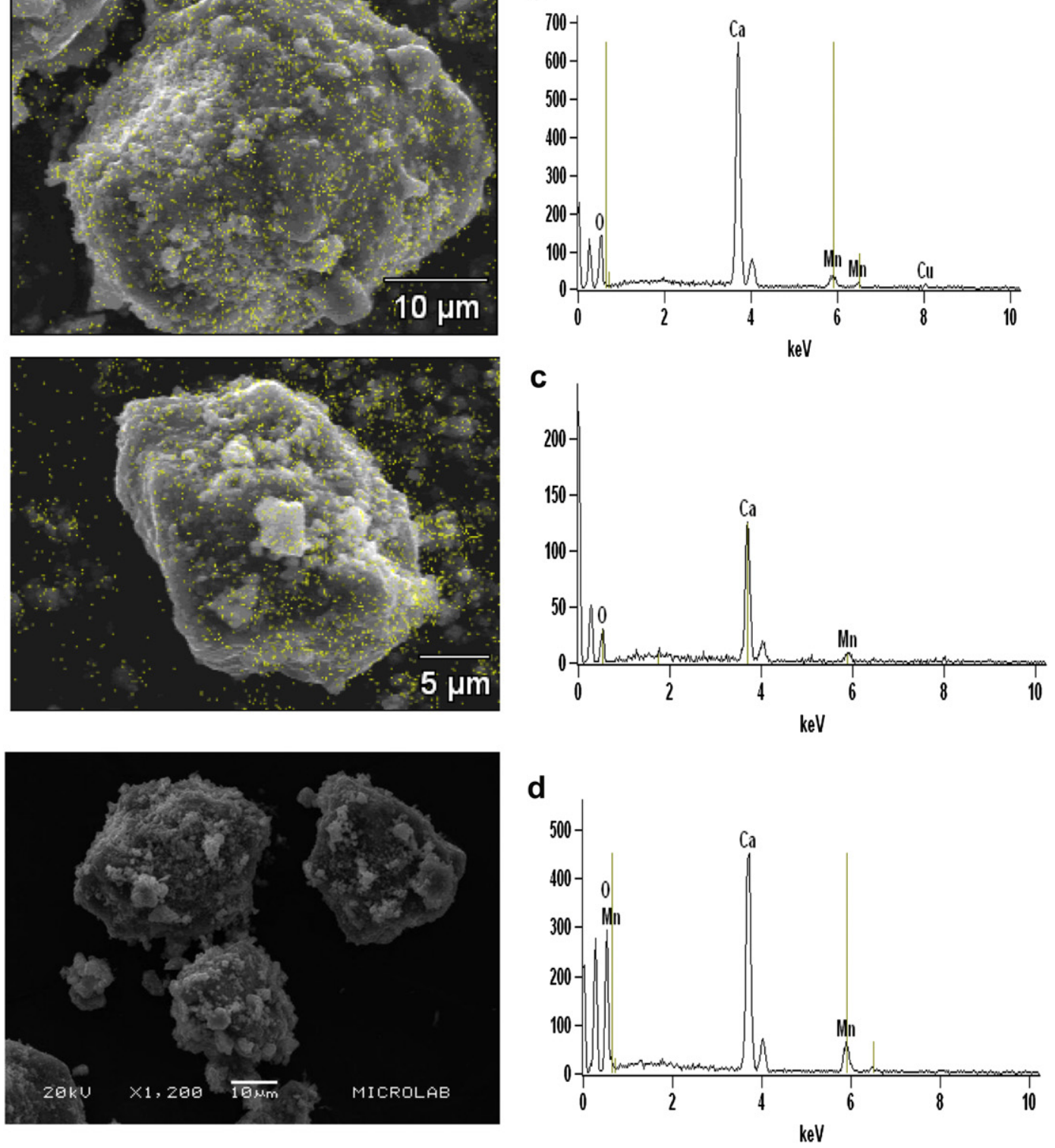

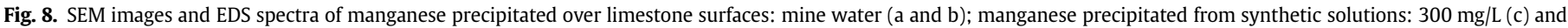
$2.0 \mathrm{~g} / \mathrm{L}(\mathrm{d})$. Manganese mapping is shown in figures (b) and (c). Experimental conditions: Batch precipitation $12.5 \mathrm{~g} / \mathrm{L}$ limestone, $23 \pm 2{ }^{\circ} \mathrm{C}$.

smelted for the production of manganese ferroalloys. Magnesium carbonate is always present in these ores and is applied in the slag production step (O'Shaughnessy et al., 2004). It can also be applied in the production of manganese dioxide, since manganese carbonate is easily soluble in sulfuric acid solutions (Zhang and Cheng, 2007a) without requiring any reducing agent. It is very likely that mine waters or process effluents with high-manganese concentrations would be generated in a manganese mine or 
a manganese producing plant. Therefore, this blending could likely be carried out in a cost-effective way.

Figs. 1-3 explain manganese removal efficiency with sodium carbonate solutions. Besides the carbonate concentration, $\mathrm{pH}$ control was also an important parameter for effective manganese carbonate precipitation, as previously stated. Manganese carbonate solubility increased quickly with acidity and even for high carbonate/metal ratios, but at lower $\mathrm{pH}$ values, precipitation might not be complete. Bamforth et al. (2006) observed low manganese removal (30\%) with a mine water containing an average of $3 \mathrm{mg} / \mathrm{L}$ manganese, at $\mathrm{pH}$ 8.1, irrespective of the solid substrate utilized. Conversely, Silva et al. (2010) observed complete manganese removal from a $16.0 \mathrm{mg} / \mathrm{L}$ mine water at $\mathrm{pH} 8.8$ with fine powdered limestone. The reason for the low removal reported by the former was likely the lower $\mathrm{pH}$ of the mine water, which could not support extensive manganese carbonate formation. For mine waters containing high-manganese and relatively low calcium and magnesium concentrations, manganese carbonate can be actually observed on limestone surfaces, provided the mine water $\mathrm{pH}$ is increased. When limestone is present, removal kinetics is improved and a denser solid residue is produced, probably having better settling features than the manganese carbonate alone. Future pilot scale experiments will aim at determining process parameters and the economics of an industrial scale process.

As discussed beforehand, water utilization in the mining industry and the effects of mining activities on water bodies have always been considered an important issue (Kemp et al., 2010). This is due to potential conflicts with nearby communities or even the country as a whole. Water has many uses in mining and therefore water storage (either clean or polluted) in dams is required in most mining operations worldwide. In wet climates, for instance tailing dams are always a concern as the discharge of excess water during wet seasons and spills (which are not uncommon) may have important environmental consequences, such as the cyanide spill observed in Guiana (Beebe, 2001) and in Romania (DeVries, 2001) in late 20th and early 21st centuries, respectively. Another issue is competition for access to water with other industries, agriculture and human use as observed in water-scarce countries (Aitchison, 2008). In this particular context, a breakthrough solution was adopted when a mining company started treating AMD and selling drink water to the neighborhood community (Hutton et al., 2009).

To summarize, water can be an important source of contaminant mobilization (Driussi and Jansz, 2006) and manganese, which has a high solubility in water bodies is one of the most difficult toxic metals to be removed. Although management measures are the most important aspect of CP (Hilson, 2000), manganese removal technologies are an important contribution for the full implementation of $\mathrm{CP}$ technologies in the mining industry.

\section{Conclusions}

Limestone-sodium carbonate blends were beneficial for manganese removal from mine waters. Sodium carbonate provided carbonate ions to precipitate high-manganese contents in mine water and industrial effluents, whereas powdered limestone induced the heterogeneous nucleation of manganese carbonate. Manganese removal efficiency was defined by $\mathrm{pH}$ with values above 8.5 resulting in massive metal removal from the solution. Manganese carbonate precipitation was confirmed by both infrared and EDS spectroscopy. Powdered limestone enhanced manganese precipitation kinetics and produced a denser solid residue with potential advantages regarding settling properties. Future work will focus on (i) the reduction of sodium carbonate consumption by increasing the solution $\mathrm{pH}$ before $\mathrm{Na}_{2} \mathrm{CO}_{3}$ addition; (ii) the chemical stability of the precipitated manganese carbonate and (iii) manganese carbonate calcining. Research on manganese removal should also address alternative solid substrates such as $\mathrm{MnO}_{2}$; limestone sorption of other species present in the mine water, i.e. sulfate, whereas field tests would determine any positive influence of soluble carbonate additions to the mine water before their passage in anoxic limestone drains, which is the main application of limestone for the treatment of mine waters.

\section{Acknowledgments}

The financial support from the funding agencies FINEP, FAPEMIG, CNPq and CAPES gratefully appreciated. The "Conselho Nacional de Pesquisas - CNPq scholarships to A. M. Silva (142546/2007) and V.A. Leão (307390/2010-1) are particularly acknowledged.

\section{References}

Abraham, K., 2006. Sustainability and gold mining in the developing world. J. Cleaner Prod. 14 (3-4), 315-323.

Aitchison, K., 2008. Competing for water. Mining Environ. Manag. 8. Dec. 07-Jan 08. Aziz, H.A., Adlan, M.N., Ariffin, K.S., 2008. Heavy metals (Cd, Pb, Zn, Ni, Cu and $\mathrm{Cr}(\mathrm{III})$ ) removal from water in Malaysia: post treatment by high quality limestone. Bioresour. Technol. 99 (6), 1578-1583.

Bamforth, S.M., Manning, D.A.C., Singleton, I., Younger, P.L., Johnson, K.L., 2006 Manganese removal from mine waters - investigating the occurrence and importance of manganese carbonates. Appl. Geochem. 21 (8), 1274-1287.

Basu, A.J., van Zyl, D.J.A., 2006. Industrial ecology framework for achieving cleaner production in the mining and minerals industry. J. Cleaner Prod. 14 (3-4), 299-304.

Beebe, R.R., 2001. Process considerations before and after failure of the Omai Tailings Dam, August 19 to 24, 1995. In: Young, C.A., Tidwell, L.G., Anderson, C.G. (Eds.), Cyanide: Social, Industrial and Economic Aspects. TMS, New Orleans, Louisiana, pp. 3-10.

Blanchard, D.L., Baer, D.R., 1992. The interactions of Co, Mn and water with calcite surfaces. Surf. Sci. 276 (1-3), 27-39.

Burger, M.S., Mercer, S.S., Shupe, G.D., Gagnon, G.A., 2008. Manganese removal during bench-scale biofiltration. Water Res. 42 (19), 4733-4742.

Cao, J., Zhang, G., Mao, Z., Fang, Z., Yang, C., 2009. Precipitation of valuable metals from bioleaching solution by biogenic sulfides. Miner. Eng. 22 (3), 289-295.

Cohen, R.R.H., 2006. Use of microbes for cost reduction of metal removal from metals and mining industry waste streams. J. Cleaner Prod. 14 (12-13), 1146-1157.

Costa, V.S.L., 2006. Tratamento de Efluentes Industriais Contendo Metais Pesados. Pontifícia Universidade Católica do Rio de Janeiro, Rio de Janeiro, Brasil, 4 pp. Available at: http://www.puc-rio.br/pibic/relatorio_resumo2008/resumos/ctc/ dcmm/dcmm_victorsl.pdf (accessed 10.10.09.).

Dayube, P.R.C., Trindade, R.B.E., 2004. Remoção de metais presentes em baixa concentração em drenagem ácida de minas. CETEM, Rio de Janeiro, 14 pp Available at: http://www.cetem.gov.br/publicacao/serie_anais_XII_jic_2004/ 27Artigo\%20JIC\%202004\%20Paula\%20dayube\%20e\%20trindade.pdf (accessed 26.07.06.).

DeVries, F.W., 2001. Brief overview of the Baia Mare dam breach. In: Young, C.A., Tidwell, L.G., Anderson, C.G. (Eds.), Cyanide: Social, Industrial and Economic Aspects. TMS, New Orleans, Louisiana, pp. 11-14.

Dharmappa, H.B., Wingrove, K., Sivakumar, M., Singh, R., 2000. Wastewater and stormwater minimisation in a coal mine. J. Cleaner Prod. 8 (1), 23-34.

Djedidi, Z., Médard, B., Cheikh, R.B., Mercier, G., Tyagi, R.D., Blais, J.-F., 2009 Comparative study of dewatering characteristics of metal precipitates generated during treatment synthetic polymetallic and AMD solutions. Hydrometallurgy 98 (3-4), 247-256.

Douglas, G., Degens, B., 2005. A Synopsis of Potential Amendments and Techniques for the Neutralization of Acidic Drainage Waters in the Western Australian Wheatbelt. CRC LEME, Bentley, WA, 22 pp. Available.

Driussi, C., Jansz, J., 2006. Technological options for waste minimisation in the mining industry. J. Cleaner Prod. 14 (8), 682-688.

Ellis, D., Bouchard, C., Lantagne, G., 2000. Removal of iron and manganese from groundwater by oxidation and microfiltration. Desalination 130 (3), 255-264.

Franks, D.M., Boger, D.V., Côte, C.M., Mulligan, D.R., 2011. Sustainable development principles for the disposal of mining and mineral processing wastes. Resour. Pol. 36 (2), 114-122.

Ghaly, A.E., Kamal, M.A., Cote, R., 2007. Effect of temperature on the performance of limestone/sandstone filters treating landfill leachate. Am.J. Environ. Sci. 3(1),11-18.

Gouzinis, A., Kosmidis, N., Vayenas, D.V., Lyberatos, G., 1998. Removal of Mn and simultaneous removal of $\mathrm{NH}_{3}$, Fe and $\mathrm{Mn}$ from potable water using a trickling filter. Water Res. 32 (8), 2442-2450.

Grosse, A.C., Dicinoski, G.W., Shaw, M.J., Haddad, P.R., 2003. Leaching and recovery of gold using ammoniacal thiosulfate leach liquors (a review). Hydrometallurgy $69(1-3), 1-21$

Grzechnik, A., Simon, P., Gillet, P., McMillan, P., 1999. An infrared study of $\mathrm{MgCO}_{3}$ at high pressure. Phys. B Condens. Matter 262 (1-2), 67-73. 
Hammarstrom, J.M., Sibrell, P.L., Belkin, H.E., 2003. Characterization of limestone reacted with acid-mine drainage in a pulsed limestone bed treatment system at the Friendship Hill National Historical Site, Pennsylvania, USA. Appl. Geochem. 18 (11), 1705-1721.

Hem, J.D., Lind, C.J., 1994. Chemistry of manganese precipitation in Pinal Creek, Arizona, USA: a laboratory study. Geochim. Cosmochim. Acta 58 (6), 1601-1613.

Hilson, G., 2000. Barriers to implementing cleaner technologies and cleaner production $(\mathrm{CP})$ practices in the mining industry: a case study of the Americas. Miner. Eng. 13 (7), 699-717.

Hilson, G., 2000. Pollution prevention and cleaner production in the mining industry: an analysis of current issues. J. Cleaner Prod. 8 (2), 119-126.

Hilson, G., 2003. Defining "cleaner production" and "pollution prevention" in the mining context. Miner. Eng. 16 (4), 305-321.

Hutton, B., Kahan, I., Naidu, T., Gunther, P., 2009. Operating and maintenance experience at the Emalahleni Water Reclamation Plant. In: International Mine Water Conference, Pretoria, South Africa, pp. 415-430.

Jimenez, R.S., Bosco, S.M.D., Carvalho, W.A., 2004. Remoção de Metais Pesados de Efluentes Aquosos pela Zeólita Natural Escolecita - Influência da Temperatura e do pH na Adsorção em Sistemas Monoelementares. Quim Nova 27 (5), 734-738.

Kemp, D., Bond, C.J., Franks, D.M., Cote, C., 2010. Mining, water and human rights: making the connection. J. Cleaner Prod. 18 (15), 1553-1562.

Lind, C.J., Hem, J.D., 1993. Manganese minerals and associated fine particulates in the streambed of Pinal Creek, Arizona, U.S.A.: a mining-related acid drainage problem. Appl. Geochem. 8 (1), 67-80.

Lloyd, A., Grzeskowiak, R., Mendham, J., 1983. The removal of manganese in water treatment clarification processes. Water Res. 17 (11), 1517-1523.

Makreski, P., Jovanovski, G., 2003. Distinction between some rhombohedral carbonates by FTIR spectroscopy. Bull. Chem. Technol. Macedonia 22 (1), 25-32.

Martins, M., Santos, E.S., Pires, C., Barros, R.J., Costa, M.C., 2010. Production of irrigation water from bioremediation of acid mine drainage: comparing the performance of two representative systems. J. Cleaner Prod. 18 (3), 248-253.

Moors, E.H.M., Mulder, K.F., Vergragt, P.J., 2005. Towards cleaner production: barriers and strategies in the base metals producing industry. J. Cleaner Prod. 13 (7), 657-668.
Nassrallah-Aboukais, N., Boughriet, A., Gengembre, L., Aboukais, A., 1998. Manganese(II)/vaterite/water systems - spectroscopic and thermodynamic study. J. Chem. Soc., Faraday Trans. 94 (16), 2399-2405.

O'Shaughnessy, P., Kim, J.K., Lee, B.W., 2004. The smelting of manganese carbonate ore. In: Jourdan, P.P., Cramer, L.A. (Eds.), Tenth International Ferroalloys Congress, pp. 223-230. Cape Town, South Africa.

Ringwood, K., Balfe, M., 2006. Strategic Water Management in the Minerals Industry. Ministerial Council on Mineral and Petroleum Resources, Canberra, 36 pp. Available at: http://www.google.com.br/url?sa $=t \& r c t=j \& q=\% 22$ strategic\% 20water\%20management $\% 22 \&$ source $=$ web\&cd $=3 \&$ ved $=0$ CDEQFjAC\&url $=$ http $\% 3 \mathrm{~A} \% 2 \mathrm{~F} \% 2$ Fwww.minerals.org.au\%2F_data\%2Fassets\%2Fpdf_file\%2F0009\%2F17 595\%2FWater_strategy_book.pdf\&ei=TukKT87BCoiqgwfolO20Cw\&usg=AFQjC NFIsSnqlje61hI1WErSHzf-GoWe6A\&cad=rja.

Santillán, J., Williams, Q., 2004. A high-pressure infrared and X-ray study of $\mathrm{FeCO}_{3}$ and $\mathrm{MnCO}_{3}$ : comparison with $\mathrm{CaMg}\left(\mathrm{CO}_{3}\right)_{2}$-dolomite. Phys. Earth Planet. Int. 143-144, 291-304.

Sheoran, A.S., Sheoran, V., Choudhary, R.P., 2010. Bioremediation of acid-rock drainage by sulphate-reducing prokaryotes: a review. Miner. Eng. 23, $1073-1100$.

Silva, A.M., Cruz, F.L.S., Lima, R.M.F., Teixeira, M.C., Leão, V.A., 2010. Manganese and limestone interactions during mine water treatment. J. Hazard. Mater. 181 (1-3), 514-520.

Sthiannopkao, S., Sreesai, S., 2009. Utilization of pulp and paper industrial wastes to remove heavy metals from metal finishing wastewater. J. Environ. Manag. 90 (11), 3283-3289.

Zhang, W., Cheng, C.Y., 2007a. Manganese metallurgy review. Part I. Leaching of ores/secondary materials and recovery of electrolytic/chemical manganese dioxide. Hydrometallurgy 89 (3-4), 137-159.

Zhang, W., Cheng, C.Y., 2007b. Manganese metallurgy review. Part II. Manganese separation and recovery from solution. Hydrometallurgy 89 (3-4), 160-177.

Zhang, W., Cheng, C.Y., Pranolo, Y., 2010. Investigation of methods for removal and recovery of manganese in hydrometallurgical processes. Hydrometallurgy 101 (1-2), 58-63. 